\title{
Implementasi Firewall Untuk Manajamen Hak Akses Web Server Berbasis Application Gateway Pada Website TNI
}

\author{
Muhamat Maariful Huda ${ }^{1, *}$, Rizqi Darma Rusdiyan Yusron ${ }^{2}$, Priska Choirina ${ }^{3}$, Mochamad Luthfi \\ Nazif Suryana ${ }^{4}$ \\ 1,2 Program Studi Ilmu Komputer, Universitas Nahdlatul Ulama Blitar, Indonesia \\ ${ }^{3}$ Program Studi Teknik Informatika, Universitas Islam Raden Rahmat, Indonesia \\ ${ }^{4}$ Program Studi Telekomunikasi Militer, Politeknik Angkatan Darat, Indonesia \\ ${ }^{1}$ hudha.maariful@unublitar.ac.id*; ${ }^{2}$ rizqidarma@unublitar.ac.id; ${ }^{3}$ priskachoirina@unira.ac.id; ${ }^{4}$ luthfinazif@gmail.com \\ * corresponding author
}

INFO ARTIKEL

\section{Sejarah Artikel}

Diterima: 5 Agustus 2020

Direvisi: 10 Oktober 2020

Diterbitkan: 30 Desember 2020

Kata Kunci

Firewall

Application Gateway

Web Server

Penetration Testing

\section{ABSTRAK}

Selaras dengan perkembangan teknologi, keamanan menjadi isu yang sangat penting, khususnya di bidang jaringan yang terhubung dengan internet. Permasalahan yang ada saat ini adalah masih adanya website negara yang dikerjakan oleh pihak luar dalam hal sistem keamanan jaringan, dan yang paling banyak menjadi sasaran kejahatan adalah web server. Daripada mempercayakan sistem keamanan web server pada pihak lain, penulis mengaplikasikan penggunaan application gateway pada firewall. Berdasarkan hasil pengujian secara keseluruhan, application gateway memiliki kinerja yang lebih baik daripada jenis firewall lain di situs web lain, memiliki kemampuan yang lebih baik dalam menangani serangan DoS, karena firewall ini bekerja tidak hanya berdasarkan pada keamanan, tujuan dan atribut paket, tetapi dapat mencapai isi paket. Hal ini menyimpulkan bahwa aplikasi gateway sesuai dan aman digunakan pada web server TNI AD.

\section{PENDAHULUAN}

Cyber Security atau keamanan dunia maya adalah proteksi perlindungan dunia maya dari sumber-sumber bahaya. Cyber security berbeda dengan security atau keamanan biasa, karena ancaman cyber tidak bisa dimasukan begitu saja ke dalam kategori keamanan tradisional. Selain berasal dari dalam negeri atau cyber threats juga datang dari luar negeri. Namun, ancaman ini jarang mencapai taraf yang membutuhkan respon militer karena apapun yang dilakukan pemerintah dalam menanggapi ancaman cyber ini akan memiliki implikasi domestik dan internasional [1]. Pesatnya perkembangan teknologi informasi dan komunikasi ini merupakan tempat diletakkannya rahasia - rahasia penting negara. Selain itu teknologi informasi dan komunikasi memiliki berbagai macam pengaruh sebagai salah satu cyber security strategi negara besar dalam menghadapi ancaman perang cyber (Cyber Warfare) dikarenakan teknologi informasi dan komunikasi memiliki berbagai fungsi [2]. Dengan adanya kekhawatiran dunia terhadap ancaman cyber warfare, maka diperlukan penerapan keamanan cyber nasional yang baik untuk memberikan perlindungan terhadap informasi yang dimiliki satuan militer.

Firewall merupakan sistem keamanan untuk mengelola dan memantau trafic masuk dan keluar berdasarkan aturan keamanan yang sudah ditentukan [3]. Firewall berfungsi mencegah akses yang tidak diinginkan dari atau ke dalam jaringan atau server. Application Gateway.adalah proxy firewall yang menyediakan keamanan jaringan [4]. Orang kebanyakan mengira bahwa firewall adalah perangkat yang diinstall pada jaringan, dan mengontrol lalu lintas yang melewati segmen jaringan. Namun, kita dapat juga memiliki 
firewall berbasis host yang dapat dijalankan pada sistem itu sendiri, seperti ICF (Internet Connection Firewall). Pada dasarnya, fungsi kedua firewall tersebut sama: untuk menghentikan intruksi dan menyediakan metode kebijakan kontrol akses kuat. Dalam definisi sederhana, firewall tidak lain adalah sistem yang melindungi komputer kita [5].

Application gateway atau dikenal dengan nama lain proxy server adalah firewall yang berfungsi untuk menyalurkan aplikasi [6]. Cara kerjanya adalah apabila ada pengguna menggunakan salah satu aplikasi seperti FTP untuk mengakses secara remote, maka gateway akan meminta client memasukkan alamat remote host yang akan dipakai. Saat Client mengirimkan userID serta informasi lainnya yang sesuai maka gateway akan melakukan hubungan terhadap aplikasi tersebut yang terdapat pada remote host, dan mengirimkan data diantara kedua titik [7]. Apabila data tersebut tidak sesuai maka firewall tidak akan meneruskan data tersebut dan menolaknya.

\section{METODE}

Pengujian implementasi Firewall untuk manajamen hak akses web server diperlukan sedikitnya ada 3 tahap yaitu tahap pengujian pada Firewall dengan metode whitelist, kemudian pengujian scanning web server dengan menggunakan OWASP ZAP dimana dalam pengujian ini adalah untuk mengetahui celah dan kerentanan terhadap dua website disini menguji website buatan sendiri dengan website dari buatan platform lain seperti wordpress, selanjutnya adalah pengujian penetration testing (Pentesting) dimana pengujian ini memberikan serangan langsung terhadap web server dengan metode serangan manual menggunakan metode SYN DDoS Attack dan SQL Injection. Selain ketiga test, dilakukan juga test kenierja web server setelah dilakukan penetration testing.

\section{HASIL DAN PEMBAHASAN}

Berikut adalah pembahasan dari 3 tahap yang sudah dilakukan:

\section{Analisa hasil pengujian Firewall dengan metode Whitelist}

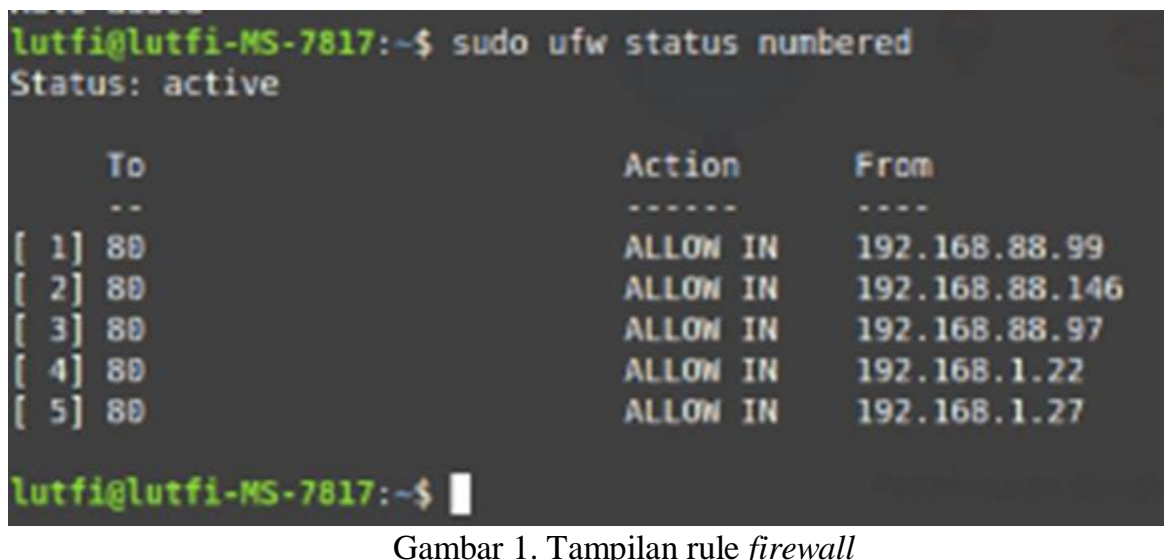

Gambar 1. Tampilan rule firewall

Pada Gambar 1 adalah pengaturan hak akses pada firewall, dimana hanya IP yang telah dimasukkan ke dalam database whitelist yang dapat mengakses webserver. Selain IP yang tersimpan dalam database tidak dapat mengakses server. Di point pengujian Firewall dengan metode whitelist, dimana firewall digunakan untuk memanajemen hak akses server dengan whitelist, perangkat manapun yang tidak terinput IP nya ke dalam server tidak dapat di izinkan masuk oleh firewall. Sesuai dengan pengujian yang telah dilaksanakan, firewall berhasil menolak akses perangkat yang tidak terinput ke dalam database. Sebaliknya setelah 
IP di input masuk ke dalam database, firewall mengizinkan masuk dan mendapatkan akses ke dalam webserver

\section{Analisa hasil pengujuan Scanning web server dengan OWASP ZAP}

Dengan metode scanning web sudah membuktikan bahwa website dan server buatan sendiri tidak kalah hebat dengan website tniad.mil.id berikut adalah perbandingan dari website sendiri dan website tniad.mil.id

Tabel 1. Hasil Scanning Web TNI AD

\begin{tabular}{|c|c|c|c|}
\hline Host & Alert Group & Severity & Alert Count \\
\hline \multirow{4}{*}{$\begin{array}{c}\text { Server } \\
\begin{array}{c}\text { Website } \\
\text { tniad.mil.id }\end{array}\end{array}$} & $\begin{array}{c}\text { Style-src unsafe-inline } \\
\text { (CORS) misconfiguration on the web } \\
\text { server }\end{array}$ & Medium & 4 \\
\cline { 2 - 4 } & Absence of Anti-CSRF tokens & Low & 2 \\
\cline { 2 - 4 } & Content-Security-Policy & Low & 4 \\
\hline
\end{tabular}

Tabel 2. Hasil Scanning Web wordpress

\begin{tabular}{|c|c|c|c|}
\hline Host & Alert Group & Severity & Alert Count \\
\hline \multirow{4}{*}{$\begin{array}{c}\text { Server } \\
\begin{array}{c}\text { Website } \\
192.168 .1 .28\end{array}\end{array}$} & \begin{tabular}{c} 
Style-src unsafe-inline \\
(CORS) misconfiguration on the web \\
\cline { 2 - 4 }
\end{tabular} & Merver & 4 \\
\cline { 2 - 4 } & Absence of Anti-CSRF tokens & Low & 2 \\
\cline { 2 - 4 } & Content-Security-Policy & Low & 4 \\
\hline
\end{tabular}

Pada Tabel 1 dan Tabel 2 terlihat persamaan dalam beberapa kerentanan, yaitu Style-src unsafe-inline atau opsi inline yang tidak aman untuk digunakan saat memindahkan atau menulis ulang baris kode pada website, pada jenis kerentanan ini resiko yang dihasilkan adalah medium dengan peringatan 4. Kerentanan selanjutnya adalah 2) COSR Misconfiguration on Web server. COSR adalah mekanisme yang memungkinkan sumber daya terbatas di laman web diminta dari domain lain di luar domain tempat sumber daya pertama ada, resiko yang dihasilan juga sama pada kedua website yaitu medium dengan jumlah peringatan sebanyak 2. Kerentanan berikutnya ada pada Absence of Anti-CSRF Tokens, hal ini terjadi karena fungsionalitas aplikasi dalam menggunakan URL / formulir yang dapat diprediksi dengan cara yang dapat diulang. Sifat serangannya adalah mengeksploitasi keamanan yang dimiliki situs web kepada pengguna dengan tingkat kerentanan low. Kerentanan yang terakhir adalah Content Security Policya atau standar keamanan komputer yang diperkenalkan untuk mencegah skrip lintas situs, clickjacking, dan serangan injeksi kode lain yang dihasilkan dari eksekusi konten berbahaya dengan tingkat kerentanan low.

\section{Analisa hasil pengujian dengan penetration testing}

Pengujian manual menggunakan SYN Ddos Attack adalah dengan cara mengirimkan paket data berjumlah 3.000.000 dan hasilnya baik website tniad.mil.id tidak terpengaruh, pada website wordpress buatan sendiri juga tidak terpengaruh. Selanjutnya dengan menggunakan SQL injection, dengan diimplementasikannya firewall pada kedua website maka serangan SQL injection tidak terpengaruh, akan tetapi jika diujicobakan pada website dengan alamat 
http://testphp.vulnweb.com maka akan dapat membuka database pada web tersebut. Pengujian selanjutnya adalah dengan menggunakan virus. Pengujian dengan menggunakan virus semua website berhasil masuk. Karena pada dasarnya firewall sendiri hanya memanajemen hak akses pada web server yang masuk dan yang keluar bukan memanajamen file yang masuk dan yang keluar, karena pada hakikatnya virus sendiri akan menyerang sistem dari server tersebut bukan pada firewall nya. Sebaliknya yang bertugas untuk mengisolasi dan mengkarantina virus hanyalah antivirus bukan firewall.

Tabel 3. Hasil pengujian menggunakan penetration testing.

\begin{tabular}{|l|l|lr|l|}
\hline & SYN DDoS Attack & SQL Injection & Virus Attack \\
\hline Tniad.mil.id & $\begin{array}{l}\text { Tidak } \\
\text { mempengaruhi }\end{array}$ & $\begin{array}{l}\text { Tidak dapat } \\
\text { menjangkau web } \\
\text { server }\end{array}$ & $\begin{array}{l}\text { Mempengaruhi } \\
\text { web server }\end{array}$ \\
\hline 192.168.1.28 & $\begin{array}{l}\text { Tidak } \\
\text { mempengaruhi }\end{array}$ & $\begin{array}{l}\text { Tidak dapat } \\
\text { menjangkau web } \\
\text { server }\end{array}$ & $\begin{array}{l}\text { Mempengaruhi } \\
\text { web server }\end{array}$ \\
\hline
\end{tabular}

\section{Tes Kinerja}

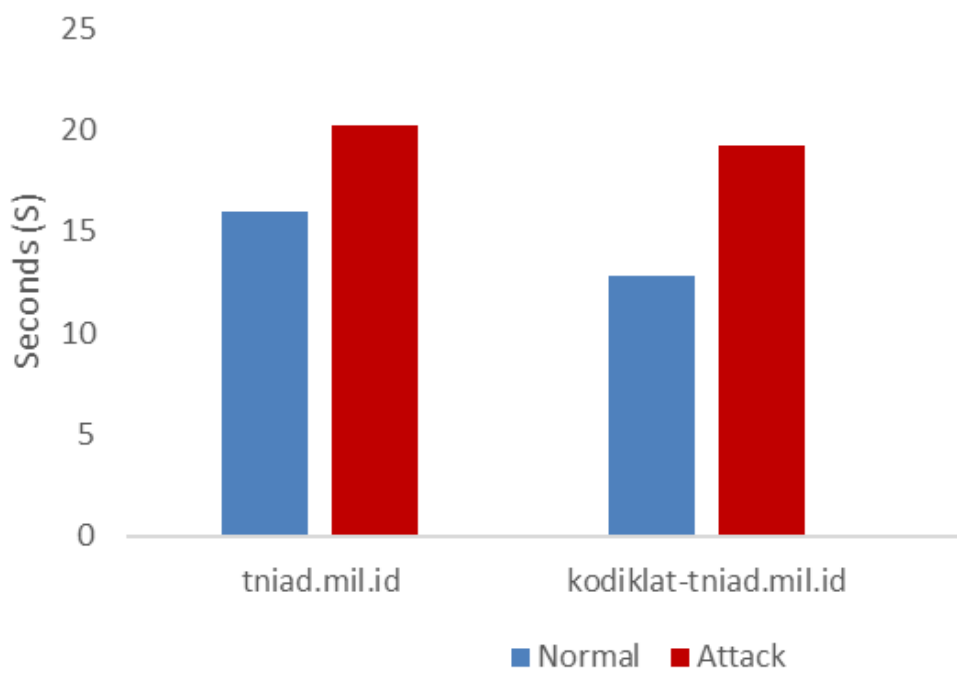

Gambar 1. Perbandingan loading webserver pada waktu normal dan pada waktu dilakukan penetration testing

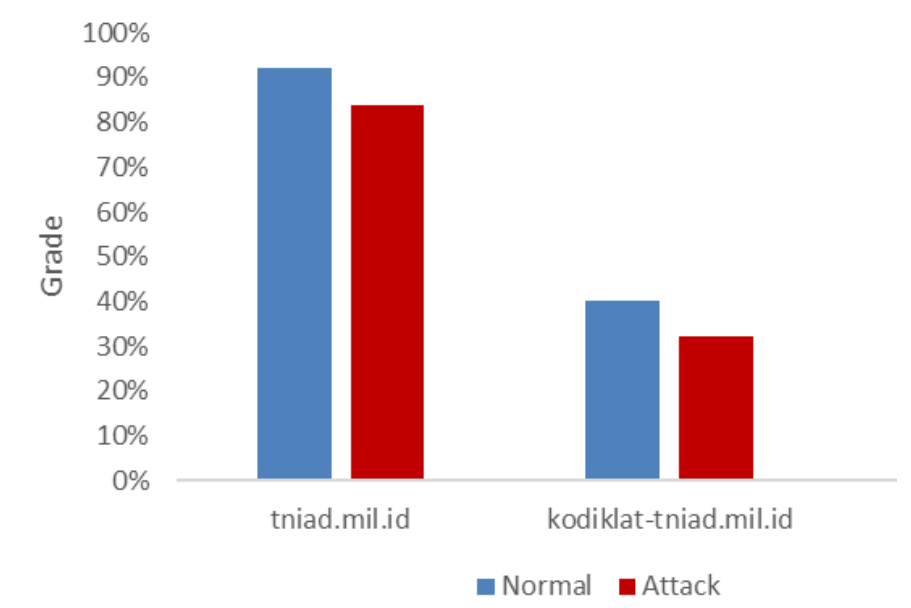

Gambar 2. Perbandingan kecepatan webserver pada waktu normal dan pada waktu dilakukan penetration testing 
Pada Gambar 1 dan 2, terdapat perbandingan waktu membuka server dan keceptan akses server pada waktu dilakukan serangan dan waktu tidak dilakukan serangan. Terlihat tidak terlalu jauh perbedaan diantara keduanya.

\section{KESIMPULAN}

Dalam penelitian ini diketahui bahwa metode application gateway untuk mengamankan web server tidak kalah dengan suatu sistem keamanan diluar perusahaan walaupun masih terdapat kekurangan, metode application gateway pada website tniad.mil.id sudah sedikit kerentanan dibandingkan situs buatan sendiri. dan juga pada tes kinerja, seperti yang kita lihat pada Gambar 1 dan 2 situs web Poltekad memiliki penurunan kinerja yang tidak cukup jauh antara pengujian normal dan tes serangan dibandingkan dengan dua besite lainnya. Kesimpulannya, penerapan poltekad Website merupakan aplikasi gateway dengan metode yang sesuai dan aman pada web server TNI AD.

\section{REFERENSI}

[1] Maheshwari R, Krishna C R and Brahma M S 2014 Defending network system against IP spoofing based distributed DoS attacks using DPHCF-RTT packet filtering technique Proc. 2014 Int.

[2] Maj S P, Makasiranondh W and Veal D 2010 An Evaluation of Firewall Configuration Methods IJCSNS Int. J. Comput. Sci. Netw. Secur. pp 1-7

[3] Azzam A T, Munadi R and Mayasari R 2019 Performance Analysis Of Firewall As Virtualized Network Function On VMware ESXi Hypervisor J. Infotel pp 11-29

[4] Gupta S and Gupta B B 2017 Cross-Site Scripting (XSS) attacks and defense mechanisms: classification and state-of-the-art Int. J. Syst. Assur. Eng. Manag. pp 512-30

[5] M. O’Leary, Cyber Operations: Building, Defending, and Attacking Modern Computer Networks. 2015.

[6] J. Scambray and S. McClure, Hacking Exposed: Windows. 2008.

[7] D. Gibson, Windows Seccurity Essential. 2011. 